\title{
THE Rise OF SPEEd DEPORTATION AND THE ROLE OF DISCRETION
}

\section{SHOBA SIVAPRASAD WADHIA*}

In 2013, the majority of people deported never saw a courtroom or immigration judge. Instead, they were quickly removed by the Department of Homeland Security via one of several procedures collectively referred to as "speed deportation." The policy goals of speed deportation are economic; these processes save government resources from being spent on procedural safeguards such as a trial attorney, immigration judge, and a fundamentally fair hearing. Higher deportation numbers may also benefit the image the government seeks to portray to policymakers who support amplified immigration enforcement. However, the human consequences of speed deportation are significant and can result in the ejection of people who would otherwise qualify for relief before an immigration judge or otherwise present strong equities like family ties, long-term residence, and steady employment in the United States. Moreover, the risk that the government may wrongly classify a person as a candidate for speed deportation is more than a remote possibility. This Article examines deportations resulting from the expedited removal, administrative removal, and reinstatement of removal orders programs and the extent to which the government has discretion to give individuals who present compelling equities, including eligibility for relief, a more complete court proceeding before an immigration judge. This Article ends with recommendations the Department of Homeland Security can take to provide a "day in court" for such individuals.

I. INTRODUCTION........................................................... 2

II. UNDERSTANDING SPEED DEPORTATION..............................6

A. What is Speed Deportation?...................................6

B. Procedural Requirements and Speed Deportation..................7

1. Reinstatement of Removal..............................7

2. Administrative Removal...................................9

3. Expedited Removal.................................. 9

C. Can Those Subject to Speed Deportation Seek a Remedy?.............. 10

* Samuel Weiss Faculty Scholar, Clinical Professor of Law and Director, Center for Immigrants' Rights, Pennsylvania State University Dickinson School of Law. The author deeply appreciates the feedback received from scholars at Penn State Law's Faculty Workshop (2014); Association of American Law Schools Conference on Clinical Education (2014); Immigration Law Teachers Workshop (2014) and the following individuals: Trina Realmuto, Jennifer Lee Koh, Margaret Taylor, and Holly Cooper. The author is grateful to the editors at Columbia Journal of Race and Law for their editorial work and Lauren Hartley (DSL '15) for her research assistance. Finally, the author thanks Penn State Law for supporting her scholarship. 
III. The Policy and Politics of Speed Deportation

A. Personal Interests Affected by Deportation..................... 14

B. Risk of Error and Value of Additional Safeguards................. 15

1. Agency Expertise....................................15

C. The Government's Interest.................................... 18

1. Improving Efficiency................................18

2. Enforcement Mission.................................20

IV. The Relationship Between Prosecutorial Discretion and Speed

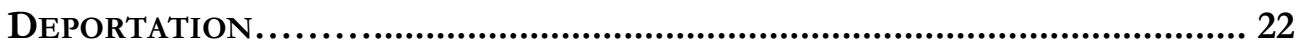

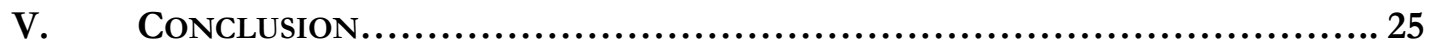

\section{INTRODUCTION}

In 2013, the majority of people deported never saw a courtroom or immigration judge. Instead, the Department of Homeland Security quickly removed them via programs termed "expedited removals", "administrative removals", 2 and "reinstatement of removal orders." 3 These programs were created by Congress and permit the agency to remove or deport a person from the United States without undertaking the formalized and exhaustive removal hearing. ${ }^{4}$ While expedited removals, administrative removals and reinstatements each apply to different sets of individuals, their common feature is a limited set of procedural protections leading to speedy removals. ${ }^{5}$ By providing comparatively fewer procedural safeguards — such as a trial attorney or an immigration judge-speed deportations promote efficient use of scarce government resources. Higher deportation numbers may also benefit the image the government

1 Immigration and Nationality Act (hereinafter, "INA") \235, 8 U.S.C. \1225 (2014); 8 C.F.R. \} 2 3 5 .

${ }^{2}$ INA \238(b), 8 U.S.C. $\$ 1228$ (2013); 8 C.F.R. \238.1.

${ }^{3}$ INA $\$ 241(a)(5), 8$ U.S.C. $\ 1231(a)(5)(2014) ;$ See 8 C.F.R. $\$ 241.8$.

${ }^{4}$ INA $\$ 240,8$ U.S.C. $\$ 1229$ (2014) (spelling out the statutory framework for a removal hearing and various "rights" and requirements that attach to such a hearing). Throughout this Article, I will use "removal proceeding", "removal hearing", and "court hearing" interchangeably.

${ }_{5}^{5}$ Throughout this Article, the phrases "speed removal" and "speed deportation" will be used interchangeably to identify one or more of the following programs: administrative removal, reinstatement of removal, and expedited removal. Stipulated removal orders, another program aimed at accelerating the removal process, are not reflected in this Article. Stipulated removal orders are authorized in the INA's command that "[ $\mathrm{t}] \mathrm{he}$ Attorney General shall provide by regulation for the entry by an immigration judge of an order of removal stipulated to by the alien (or the alien's representative) and the Service. A stipulated order shall constitute a conclusive determination of the alien's removability from the United States.” INA \240(d), 8 U.S.C. \1229(d) (2014). One reason I do not include stipulated removal orders is that unlike the speed removal programs identified above, immigration judges participate in the stipulated removal program and are required to memorialize the removal order. For a thoughtful analysis focused on the stipulated removal order program, see Jennifer Lee Koh, Waiving Due Process (Goodbye): Stipulated Orders of Removal and the Crisis in Immigration Adjudication, 91 N.C.L. REV. 475 (2013). 
seeks to portray to policymakers who support stricter immigration enforcement. However, the human consequences of speed deportation are significant and can result in the ejection of people who would otherwise qualify for relief before an immigration judge or who present strong equities like family ties, long-term residence, or steady employment in the United States. Moreover, the risk that the government may wrongly classify a person as a candidate for speed deportation is more than a remote possibility. This Article examines deportations resulting from the expedited removal, administrative removal, and reinstatement of removal orders programs. It also examines the extent to which the government has discretion to give individuals who present compelling equities, including eligibility for relief, a more complete court proceeding before an immigration judge.

In the last several years, the vast majority of removals have been in the form of speed deportation, but little scholarship has explored the legitimacy of these programs. ${ }^{6}$ The data on removals from recent years suggests that a fraction of people are placed in removal proceedings and heard by an immigration judge before a removal order is entered. Of the approximately 438,000 non-citizens deported in 2013, 193,032 were removed through expedited removal and 170,247 were subject to a reinstated final order. ${ }^{7}$ Thus, $82.8 \%$ of all removals in 2013 were comprised of expedited removals and reinstatements. By contrast, at most 75,142 or $17 \%$ of those deported were removed following a removal order issued by an immigration judge within the Executive Office for Immigration Review ("EOIR"). ${ }^{8}$ Data from 2013 reveals a similar proportion': 438,421 noncitizens were removed from the United States, of which 193,032 or $44 \%$ were removed through expedited removal orders and 170,247 or $38.8 \%$ were removed through reinstatements. ${ }^{10}$ Likewise, 9,217 of these removals were enacted through administrative removal orders. ${ }^{11}$ These numbers reveal the extent to which DHS removed individuals without a day in court. The proportions of speed removals in 2012 and 2013 in contrast to removal orders that followed a court hearing are striking and illustrate how greatly DHS relies on speed removal programs to carry out its mission to enforce the immigration laws. ${ }^{12}$

Cumulatively, the numbers reveal that for the last several years, more than half of the total population removed from the United States has bypassed a courtroom through a speed deportation program. Accordingly, it would be imprecise to conclude that the number of speed removals in the last

${ }^{6}$ The author acknowledges earlier work by Jill Family examining “diversions” from immigration removal proceedings and by Jennifer Lee Koh examining "stipulated removal" orders that enable a removal without a hearing. See Jill E. Family, A Broader View of the Immigration Adjudication Problem, 23 GEO. IMMIGR. L. J. 595 (2009); Koh, supra note 5. However, these works do not dissect the speed deportation programs that are the subject of this Article.

7 JOHn F. SimANSKI, DHS OFFICE OF IMMIGRATION STATISTICS, IMMigRATION ENFORCEMENT ACTIONS: 2013 5, Table 6, (Sept. 2014), available at

http://www.dhs.gov/sites/default/files/publications/ois_enforcement_ar_2013.pdf.

${ }^{8}$ Id. The number of removal orders issued by an immigration judge within EOIR may in fact be lower than 75,142 , as this data does not categorize administrative removal orders for 2013 . This inquiry, however, is beyond the scope of this Article.

9 Id.

${ }^{10} I d$.

${ }^{11}$ Email from John Simanski, Office of Immigration Statistics, Dep't. of Homeland Sec., to author (Oct. 27, 2014, 9:11 EST) (on file with author).

12 The statistics from earlier years also reveal that the majority of individuals removed from the United States underwent "speed deportation" through expedited removal or reinstatement, not administrative removal. For example, data from 2011 shows that "[r] einstatements of final orders accounted for 130,000, or 33 percent, of all removals. Expedited removals accounted for 123,000, or 31 percent, of all removals." Data from 2010 shows that "[r] einstatements of final orders accounted for 131,000, or 34 percent, of all removals. Expedited removals accounted for 111,000, or 29 percent, of all removals.” OFFICE OF IMMIGRATION STATISTICS, POLICY DiRECTORATE, ANNUAL REPORT: IMMIGRATION ENFORCEMENT ACTIONS 1 (2010), available at http://www.dhs.gov/xlibrary/assets/statistics/publications/enforcement-ar-2010.pdf. 
year served as a counterbalance to the growth in humanitarian programs like deferred action for childhood arrivals ("DACA"), ${ }^{13}$ guidance documents on prosecutorial discretion, ${ }^{14}$ and other administrative programs designed to protect people with equities from deportation through non-enforcement programs. Data from prior to 2009 reveals different trends in removals. ${ }^{15}$ For example, in 2001, 38,943 individuals were removed through reinstatement orders (compared to 149,000 in 2013). ${ }^{16}$ Moreover, DHS published neither a definition for, nor data on, reinstatements from 2004-2008.17

This Article focuses on the discretion held by the Department of Homeland Security ("DHS") to place noncitizens legally eligible for speed removal into a complete court proceeding ("removal proceedings") before an immigration judge. "Prosecutorial discretion" identifies the authority for DHS to decide whether and to what extent to enforce the immigration laws against a person or group of persons. My interest in exploring the growth and consequences of speed removal is tied not only to my intellectual journey into the role of prosecutorial discretion ${ }^{18}$ in immigration law but also to personal experience. In Fall 2013, the clinic I direct at Penn State Law took on a pro bono case involving a man detained in York County Prison who received an administrative removal order. Consequently, he was stripped of the process and rights he might have otherwise been provided in a regular immigration court proceeding. Our client had immediate family members who were United States citizens and, in our view, was wrongly classified by DHS as an aggravated felon. Because his removal was predetermined by DHS through a speed deportation program, he was not afforded the opportunity to challenge his removability or apply for relief in removal proceedings. Instead, our client was issued a removal order and placed into a narrow forum called "withholding only" proceedings, a forum described in greater detail below.

${ }^{13}$ Consideration of Deferred Action for Childhood Process, U.S. CITIZENSHIP AND IMMIGRATION SERVICES, DEPARTMENT OF HOMELAND SECURITY, http://www.uscis.gov/humanitarian/consideration-deferred-actionchildhood-arrivals-process (last visited March 10, 2014).

14 See Memorandum from John Morton, Director, U.S. Immigration \& Customs Enforcement to ICE employees (Mar. 2, 2011) (available online at http://www.ice.gov/doclib/news/releases/2011/110302washingtondc.pdf); see also Memorandum from John Morton, Director, U.S. Immigration \& Customs Enforcement to ICE employees (June 17, 2011) (available online at http://www.ice.gov/doclib/secure-communities/pdf/prosecutorial-discretion-memo.pdf); see also Shoba Sivaprasad Wadhia, Reflections on Prosecutorial Discretion One Year After the Morton Memo, LEXISNeXIs ImmigRATION LAw BLOG (June 14, 2012, 4:05 PM), http://www.lexisnexis.com/legalnewsroom/immigration/b/immigration-law-

$\mathrm{blog} /$ archive/2012/06/21/reflections-on-prosecutorial-discretion-in-immigration-context-1-year-after-the-mortonmemo.aspx.

15 For example, data from 2004 indicates a reduction in expedited removals from the previous year. Expedited removals represented $21 \%$ of all formal removals in 2004. MARY DOUGHERTY ET AL., DHS OFFICE OF IMMIGRATION STATISTICS, IMMIGRATION ENFORCEMENT ACTIONS: 20041 (2005), available at http://www.dhs.gov/xlibrary/assets/statistics/publications/AnnualReportEnforcement2004.pdf.

16 See id.

17 See Yearbook of Immigration Statistics, DEP’T. OF HOMELAND SEC., https://www.dhs.gov/yearbookimmigration-statistics (last visited Mar. 30, 2014).

18 See, e.g., Shoba Sivaprasad Wadhia, Immigration Remarks for the 10th Annual Wiley A. Branton Symposium, 57 How. L.J. 931 (2014); Shoba Sivaprasad Wadhia, My Great FOIA Adventure and Discoveries of Deferred Action Cases at ICE, 27 Geo. Immigr. L.J. 345 (2013); Shoba Sivaprasad Wadhia, In Defense of DACA, Deferred Action, and the DREAM Act, 91 TEx. L. REV. 59 (2013); Shoba Sivaprasad Wadhia, The Immigration Prosecutor and the Judge: Examining the Role of the Judiciary in Prosecutorial Discretion Decisions, 16 Harv. LATINO L. REV. 39 (2013); Shoba Sivaprasad Wadhia, The Role of Prosecutorial Discretion in Immigration Law, 9 CONN. PUB. INT. L.J. 243 (2010); SHOBA SIVAPRASAD WADHIA, THE MORTON MEMO AND ProseCUtORIAL DisCretion: AN OvERVIEW (2011), available at http://www.immigrationpolicy.org/specialreports/morton-memo-and-prosecutorial-discretion-overview; SHOBA SIVAPRASAD WADHIA, READING THE MORTON MEMO: FEDERAL PRIORITIES AND PROSECUTORIAL DisCRETION (2010), available at http://www.immigrationpolicy.org/special-reports/reading-morton-memo-federal-priorities-and-prosecutorialdiscretion. 
To facilitate the analysis of the programs analyzed for this Article and how they interact with discretion generally, a short background of the history of U.S. immigration policy is in order. DHS is a cabinet-level agency that was created after the terrorist attacks of September 11, 2001. ${ }^{19}$ DHS is composed of multiple sections, three of which play a robust role in immigration: Customs and Border Protection ("CBP"), ${ }^{20}$ Immigration and Customs Enforcement ("ICE"), ${ }^{21}$ and United States Citizenship and Immigration Services ("USCIS").22 While both ICE and CBP play a significant role in apprehending and processing noncitizens for removal, ${ }^{23}$ ICE bears responsibility for executing removal orders. In this way, when ICE apprehends, detains, and processes noncitizens for speed removal, it serves as the police, jailor, and judge. ${ }^{24}$

A second agency responsible for making decisions about deportation is the Department of Justice ("DOJ"). Within DOJ is a unit called the EOIR, which itself is comprised of more than 250 immigration judges and 59 immigration courts throughout the United States, as well as an administrative appellate division known as the Board of Immigration Appeals ("BIA"). ${ }^{25}$ While an immigration judge or BIA member is not herself independent from the Executive Branch or elected for an indefinite period like an Article III judge, ${ }^{26}$ she functions like an administrative law judge and is bound by regulation to exercise independent judgment when conducting proceedings. ${ }^{27}$ In 2013, immigration judges handled 193,350 cases, 187,677 of which were removal proceedings. 28 Other case types heard by immigration judges include: deportation proceedings, exclusion proceedings, and review of negative, credible, or reasonable fear findings by the asylum officer, among other proceedings. ${ }^{29}$ Individuals in removal proceedings enjoy
${ }^{19}$ Homeland Security Act of 2002, Pub. L. No. 107-296, 116 Stat. 2135 (2002).
20 About CBP, U.S. CUSTOMS \& BORDER PROT., http://www.cbp.gov/about/ (last visited Mar. 10, 2014).
21 Overview, U.S. IMMIGRATION \& CUSTOMS ENFORCEMENT, http://www.ice.gov/about/overview/ (last visited Mar. 10, 2014).

22 About Us, U.S. Citizenship \& IMMigRATION SERVICES, http://www.uscis.gov/aboutus (last visited Mar. 10, 2014).

23 See, e.g., FY 2013 ICE Immigration Removals, U.S. IMMIGRATION \& CuSTOMS ENFORCEMENT, https://www.ice.gov/removal-statistics/ (last visited Mar. 10, 2014).

24 Only in the administrative removal process does the legal framework call for the arresting officer to be different from the deciding officer. See INA \ 238(b)(4)(F), 8 U.S.C. $\int 1228(b)(4)(F)(2013) ; 8$ C.F.R. \ 238.1 (defining "deciding service officer" as "a district director, chief patrol agent, or another immigration officer designated by a district director, chief patrol agent, the Deputy Executive Associate Commissioner for Detention and Removal, or the Director of the Office of Juvenile Affairs, so long as that person is not the same person as the Issuing Service Officer.").

25 About, Office of the Chief Immigration Judge, EXEC. OFFICE OF IMMIGRATION REVIEW, U.S. DEP'T OF JUSTICE, http://www.justice.gov/eoir/ocijinfo.htm (last visited Mar. 10, 2014).

${ }^{26}$ For a critique of the lack of independence of immigration judges and suggestions that the immigration system reform and use Article III judges see Stephen H. Legomsky, Restructuring Immigration Adjudication, 59 DUKE L.J. 1635 (2010).

27 See, e.g., 8 C.F.R. S 1003.10(b). ("In conducting hearings under section 240 of the Act and such other proceedings the Attorney General may assign to them, immigration judges shall exercise the powers and duties delegated to them by the Act and by the Attorney General through regulation. In deciding the individual cases before them, and subject to the applicable governing standards, immigration judges shall exercise their independent judgment and discretion and may take any action consistent with their authorities under the Act and regulations that is appropriate and necessary for the disposition of such cases."). Likewise, since the immigration court system sits within DOJ, there is a level of independence it has from ICE, which houses the attorneys responsible for defending the government in removal proceedings. But attorneys who represent the government in federal court proceedings at which noncitizens challenge final orders of removal are housed within DOJ in an office dubbed the Office of Immigration Litigation (OIL). See About, Office of Litigation, U.S. DEP’T OF JUSTICE, http://www.justice.gov/civil/office-immigration-litigation (last visited Mar. 25, 2014).

${ }^{28}$ U.S. DEP’T OF JUSTICE EXEC. OFFICE FOR IMMIGRATION REVIEW, FY 2013 STATISTICAL YEARBOOK B1 (2014), available at http://www.justice.gov/eoir/statspub/fy13syb.pdf.

${ }^{29}$ Id. As summarized by the EOIR Yearbook, "deportation case" refers to "[a] case type initiated when the former Immigration and Naturalization Service [INS] filed an Order to Show Cause with an immigration court before 
fundamental protections. Among the safeguards provided to such individuals are the right to counsel at no expense to the government, the right to examine evidence, the right to present evidence and witnesses, the right to cross-examine the government's witnesses, the right to contest the allegations charged, the right to apply for relief from removal, and the right to file an administrative appeal from a negative decision by the immigration judge to the BIA. ${ }^{30}$ Individuals may be able to raise a due process challenge in removal proceedings in federal court. ${ }^{31}$

\section{UNDERSTANDING SPEED DEPORTATION}

\section{A. What is Speed Deportation?}

For this Article, "speed deportation" refers to three programs operated by the Department of Homeland Security to process and remove noncitizens without a hearing before an immigration judge. These programs are creatures of Congress and are authorized in three provisions of the immigration statute as: (1) expedited removal, (2) reinstatement, and (3) administrative removal. Expedited removal applies to persons who arrive at a port-of-entry or within 100 miles of the border with fraudulent or insufficient documents. ${ }^{32}$ Reinstatement applies to persons who "reenter" the United States without authorization after having departed the United States voluntarily or under a previous removal order. The order of removal is "reinstated" from the original date of the person's original departure or removal order. ${ }^{33}$ Administrative removal applies to noncitizens who are not permanent residents of the United States and

April 1, 1997," id. at 6; and "exclusion case" refers to "[a] case type involving a person who, before April 1, 1997, tried to enter the United States but was stopped at the port of entry because the former [INS] found the person to be inadmissible," Id. A full description of these proceedings here is limited because they are not a focus of this Article. ${ }^{30}$ INA \240(b)(4), 8 U.S.C. $\int 1229(b)(4)(2014)$.

31 See, e.g., Abdulai v. Ashcroft, 239 F.3d 542, 549 (3d Cir.2001) (“[A]liens facing removal are entitled to due process, which includes opportunity to make arguments on their own behalf'); see also Leslie v. Attorney Gen. of U.S., 611 F.3d 171, 181 (3d Cir. 2010) ("Aliens in removal proceedings are entitled to Fifth Amendment Due Process protection, which guarantees them a fundamentally fair removal hearing."). It should be pointed out that "regular" removal proceedings have been criticized by scholars and advocates for lacking the safeguards available to defendants in criminal proceedings, in part, because the former are considered "civil." For a greater discussion on this topic, see Juliet Stumpf, The Crimmigration Crisis: Immigrants, Crime, and Sovereign Power, 56 AM. U. L. REV. 367 (2006); Stephen H. Legomsky, The New Path of Immigration Law: Asymmetric Incorporation of Criminal Justice Norms, 64 WASH. \& LEE L. REV. 469 (2007); Peter L. Markowitz, Straddling the Civil-Criminal Divide: A Bifurcated Approach to Understanding the Nature of Immigration Removal Proceedings, 43 HARV. C. R.-C. L. L. REV. 289 (2008).

32 See INA \235(b)(1)(A)(i), 8 U.S.C. \$1225(b)(1)(A)(i) (2013) (providing that "[i]f an immigration officer determines that an alien (other than an alien described in subparagraph $(\mathrm{F})$ ) who is arriving in the United States or is described in clause (iii) is inadmissible under section 212(a)(6)(C) or 212(a)(7), the officer shall order the alien removed from the United States without further hearing or review unless the alien indicates either an intention to apply for asylum under section 208 or a fear of persecution.”); 8 C.F.R. S235.3. See also SimANSKI, supra note 7, at 2 (defining "expedited removal" as "removal without a hearing before an immigration judge of an alien arriving in the United States who is inadmissible because the individual does not possess valid entry documents or is inadmissible for fraud or misrepresentation of material fact; or the removal of an alien who has not been admitted or paroled in the United States and who has not affirmatively shown to the satisfaction of an immigration officer, that the alien had been physically present in the United States for the immediately preceding 2-year period (INA $₫ 235(\mathrm{~b})(1)(\mathrm{A}))$.”).

33 See INA \241(a)(5), 8 U.S.C. \1231(a)(5) (2013) (providing that "[i]f the Attorney General finds that an alien has reentered the United States illegally after having been removed or having departed voluntarily, under an order of removal, the prior order of removal is reinstated from its original date and is not subject to being reopened or reviewed, the alien is not eligible and may not apply for any relief under this Act, and the alien shall be removed under the prior order at any time after the reentry"); see also 8 C.F.R. S 241.8; SIMANSKI, supra note 7, at 2 (defining reinstatement of "final removal orders" as "[t]he removal of an alien on the reinstatement of a prior removal order, where the alien departed the United States under an order of removal and illegally re-entered the United States (INA \ 241(a)(5)). The alien may be removed without a hearing before an immigration judge."). 
have been classified by DHS as convicted of an aggravated felony. ${ }^{34}$ One complication is defining "aggravated felony." Currently, the immigration code (hereinafter, "INA") lists more than one dozen categories for aggravated felony ${ }^{35}$ including: theft offenses, crimes of violence, drug trafficking, murder, and fraud offenses involving at least a $\$ 10,000$ loss to the victim. ${ }^{36}$ The next section discusses the procedural protections and substantive remedies that do attach to speed deportation.

\section{B. Procedural Requirements and Speed Deportation ${ }^{37}$}

In theory, the procedural safeguards included in the statute and regulations for reinstatement of removal, expedited removal, and administrative removal contains more "process" than other deportation schemes such as the stipulated removal order program ${ }^{38}$ and those subject to in absentia orders of removal. ${ }^{39}$ Moreover, the legal framework for speed deportation enables a party to challenge his speed removal in a federal court. The procedural safeguards associated with speed deportation are detailed in this section. Practically speaking, however, noncitizens face significant hurdles, including the short period one has to challenge removal, and the inability to obtain evidence, understand the nature of the charges, or secure counsel.

\section{Reinstatement of Removal}

Under the reinstatement regulations, DHS is required to make the following findings: whether (1) the alien was subject to a prior order of removal, (2) the alien is the same person as the one named in the prior order, and (3) the alien unlawfully reentered the country. ${ }^{40}$ In making a determination about whether the individual has unlawfully entered, the regulations require that DHS "consider all relevant evidence, including statements made by the alien and any evidence in the alien's possession. The immigration officer shall attempt to verify an alien's claim, if any, that he or she was lawfully admitted, which shall include a check of Service data systems available to the officer." 41 Procedurally, the reinstatement of removal process

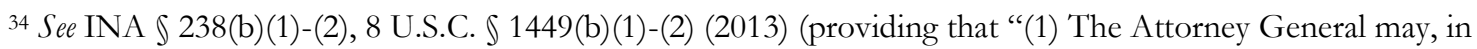
the case of an alien described in paragraph (2), determine the deportability of such alien under section 237(a)(2)(A)(iii) (relating to conviction of an aggravated felony) and issue an order of removal pursuant to the procedures set forth in this subsection or section 240. (2) An alien is described in this paragraph if the alien- (A) was not lawfully admitted for permanent residence at the time at which proceedings under this section commenced; or (B) had permanent resident status on a conditional basis (as described in section 216) at the time that proceedings under this section commenced."); 8 C.F.R. \238.1(b)(1); INA \101(a)(43), 8 U.S.C. \1101(a)(43) (2013). See also SIMANSKI, supra note 7, at 2 (defining "Administrative Removal" as " $\mathrm{t}]$ he removal of an alien not admitted for permanent residence, or of an alien admitted for permanent residence on a conditional basis pursuant to section 216 of the INA, under a DHS order based on the determination that the individual has been convicted of an aggravated felony (INA $\int 238(b)(1)$ ). The alien may be removed without a hearing before an immigration judge.").

35 INA \ 101(a)(43), 8 U.S.C. \1101(a)(43) (2013).

36 See id.

37 Outside the scope of this Article but worthy of a mention is the extent to which a person can challenge a decision by DHS to place a person in speed removal under administrative law. Possibly, the decision made by DHS to place a person in administrative removal or reinstatement is an arbitrary one in which the officer can either a) place the same individual in a full removal proceeding, at which she can apply for any form of relief from removal before an immigration judge, or b) issue an administrative or reinstatement of removal order at which the best she can hope for if she has passed her "reasonable fear" interview before an asylum officer is mandatory withholding or Convention Against Torture protection. This argument is propelled by the fact that neither the statute nor the regulations contain guidance on how, or the circumstances under which, DHS should elect between placing a person in speed deportation or issuing and filing an NTA to commence removal proceedings.

${ }^{38}$ INA \240(d), 8 U.S.C. \1229a(d) (2013); 8 C.F.R. \1003.25(b); see also, Koh, supra note 5.

39 INA \240(b)(5), 8 U.S.C. \1229a(b)(5) (2013); 8 C.F.R. \ 1003.26 (defining in absentia hearings).

40 See 8 C.F.R. \$241.8(a)(1)-(3).

418 C.F.R. $\int 241.8(a)(3)$. 
commences when a DHS officer provides the noncitizen with a written notice of his determination. ${ }^{42}$ The regulations require DHS to provide a noncitizen with written notice of its decision if it determines that the noncitizen is subject to reinstatement. DHS must also advise the noncitizen about his ability to contest a reinstatement finding and reconsider his decision if a challenge is made. ${ }^{43}$ Additionally, the regulations require that individuals who express fear of persecution upon return be referred to an asylum officer for additional screening. ${ }^{44}$ Furthermore, another section of the regulations, outside of those that govern reinstatement of removal, clarifies that any person who is subject to an "examination" (which would include reinstatement of removal) has a right to counsel. 45

While the regulations that govern reinstatement cases are seemingly long, the actual amount of time needed for removal is sometimes short. Professor Lee J. Terán has noted, "[in] most cases, particularly involving Mexicans arrested near the U.S./Mexico border, the process of reinstatement of removal can be completed in a matter of hours." 46 Though the regulations provide an internal procedure for challenging speed deportation, a noncitizen's inability to appeal a removal order to a neutral third party (an immigration judge or BIA) is troubling. ${ }^{47}$

Individuals who receive a reinstatement order may challenge its legality in a federal court of appeals through a legal vehicle called a "petition for review." The statutory language that governs judicial review states that a "petition for review" is the exclusive means of review for final orders of removal. ${ }^{48}$ A petition for review must be filed within 30 days after a reinstatement of removal order becomes final. Under the statute, a petition for review "shall be filed with the court of appeals of the judicial circuit in which the immigration judge completed the proceedings." 49 This creates ambiguity for people in reinstatement because those orders are unilaterally issued by DHS. Therefore, reinstatement orders do not involve immigration judges unless the person is in reasonable fear proceedings, which as detailed in the following section, are triggered only after a person has been found to have a "reasonable fear" of persecution or torture. Moreover, even the order underlying a reinstatement order may have been issued by DHS rather than by an immigration judge. Some federal courts have rejected procedural due process challenges to reinstatement of removal orders. ${ }^{50}$

While it may be true that judicial review is available for those who wish to challenge a final order of removal following a reinstatement of removal order, in reality the statutory limitations and practical impediments to filing a petition to review in a circuit court make such review difficult. For example, the person may be unfamiliar with his options for federal court review before he is deported because he lacks counsel, information, or the will to remain in detention to fight his case. Moreover, many of the forms associated with speed deportation are in English and also lack information about the availability of judicial review. Lastly, filing a petition for review does not automatically "stay" a person's deportation, so DHS can execute a removal order notwithstanding a timely filed petition for review.

428 C.F.R. $\$ 241.8(b)$.

${ }^{43} I d$.

448 C.F.R. $\$ 241.8(\mathrm{e})$.

458 C.F.R. $\int 292.5$ (b).

${ }^{46}$ Lee. J. Terán, Mexican Children of U.S. Citizens: "Vignes Prin" and Other Tales of Challenges to Asserting Acquired U.S. Citizenship, 14 SCHOLAR 583, 661 (2012). In 2013, 75\% of all reinstatements were applied to nationals of Mexico. See SIMANSKI, supra note 7.

47 See, e.g., INA \241(a)(5), 8 U.S.C. \1231(a)(5) (2013).

${ }^{48}$ INA \242(a)(5), 8 U.S.C. \$1252(a)(5) (2013).

${ }^{49} I d$.

50 See, e.g., Morales-Izquierdo v. Gonzales, 486 F.3d 484, 496 (9th Cir. 2007) ("We are satisfied, moreover, that the [reinstatement] regulation provides sufficient procedural safeguards to withstand a facial challenge for patent procedural insufficiency.”). 


\section{Administrative Removal}

The statutory language that governs administrative removal requires DHS to provide an individual with reasonable notice of the charges, notice of his right to be represented by counsel at no expense to the government, the right to inspect, examine and rebut evidence, and service of the record in person or by mail, among other requirements. ${ }^{51}$ The regulations for administrative removal proceedings also contain important requirements. Administrative removal proceedings commence when a noncitizen is served with a charging document called the "Notice of Intent to Issue a Final Administrative Removal Order." 52 This Notice includes information about the grounds for removal, the ability for a noncitizen to seek counsel at no expense to the government, the opportunity to apply for withholding of removal if he fears persecution or torture in his country of removal, and the ability to challenge his 238(b) classification. ${ }^{53}$ This Notice must also be accompanied by a list of free local legal services. In the absence of a challenge by the noncitizen, or if DHS finds that the noncitizen's rebuttal lacks a genuine issue affecting its findings of removability, the removal order is executed within 14 days unless the 14 day period is waived. ${ }^{54}$ Likewise, administrative removal orders require a supervisor to finalize the order. ${ }^{55}$ If DHS ultimately finds that a noncitizen is not properly subject to administrative removal, an officer can terminate the administrative removal proceedings and place the individual in "regular" removal proceedings by issuing a Notice to Appear. ${ }^{56}$ DHS is required to refer individuals to an asylum officer for additional screening if such individuals request to apply for protection under withholding of removal..$^{57}$

Like with reinstatement, individuals who face an administrative removal order may file a "petition for review" within 30 days after an administrative removal order becomes final. Notably, judicial review is specifically mentioned in the statutory provision that governs administrative removal. Specifically, the statute requires a record be "maintained for judicial review." 58 With respect to those otherwise precluded from seeking judicial review because of a statutory bar (such as a person found removable because of an aggravated felony), the immigration statute preserves jurisdiction for claims involving legal questions and constitutional claims..$^{59}$ Nevertheless, the practical impediments faced by those in administrative removal are similar to the reinstatement context insofar as they may lack the information about judicial review. Also, since the timeline for administrative removal is a short one (14 days), the likelihood is very high that people are wrongfully removed before a court of law can conclude that a particular crime is not, in fact, an aggravated felony.

\section{Expedited Removal}

In the expedited removal process, a DHS officer should advise the noncitizen of the charges against him in writing and provide him with an opportunity to respond. ${ }^{60}$ Like with administrative removal, expedited removal orders are entered by a DHS examining officer after they have been approved by a

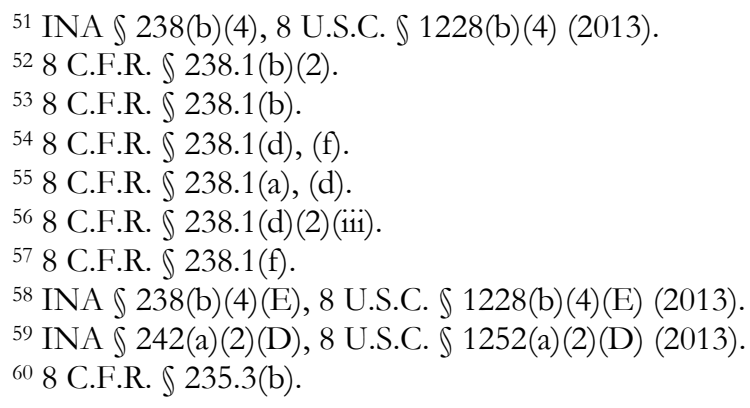


supervisor. ${ }^{61}$ If a noncitizen who is subject to expedited removal indicates a fear of return to his home country, then DHS shall record this information and provide the noncitizen with a written description of the "credible fear" interview process, notice of the right to consult with others before the interview, and other information. ${ }^{62}$ Verified lawful permanent residents, refugees, asylees, or United States citizens, may not be removed pursuant to expedited removal. The regulations contain a narrow procedure for handling related claims. ${ }^{63}$ For example, when someone in expedited removal claims to be a United States citizen, the claim must be heard by an immigration judge in a proceeding called "claimed status review." 64

In expedited removal cases, judicial review is limited to habeas corpus challenges based on status claims, such as whether the individual is a citizen, lawful permanent resident, asylee, or refugee and whether the person was ordered removed. ${ }^{65}$

\title{
C. Can Those Subject to Speed Deportation Seek a Remedy?
}

Importantly, a fraction of individuals subject to expedited removal, administrative removal, or reinstatement of removal may have the opportunity to apply for protection from harm before an immigration court. This outcome is limited, however, to those who are able to convince an asylum officer that their fear of persecution or torture is "reasonable" if the person is subject to reinstatement or administrative removal or "credible" if the person is subject to expedited removal. ${ }^{66}$ If an asylum officer within USCIS concludes that an arriving asylum seeker subject to expedited removal has a "credible fear" of persecution or torture in her home country, then she will fill out the requisite worksheet and file the necessary paperwork with the immigration court to initiate a regular removal hearing at which she can apply for asylum, withholding of removal and/or protection under the Convention Against Torture ("CAT") before an immigration judge. ${ }^{67}$ Individuals who pass their credible fear interview are served with a Notice to Appear ("NTA") and placed into formal removal proceedings once the NTA is filed with the immigration court. ${ }^{6}$ In this way, asylum seekers who ordinarily may have been subject to expedited

\author{
618 C.F.R. \235.3(b)(7). \\ 628 C.F.R. $\int 235.3(\mathrm{~b})(4)$. \\ 63 8 C.F.R. $\int 235.3(\mathrm{~b})(5)$. \\ ${ }^{64} \mathrm{Id}$. \\ 65 See, e.g., Smith v. U.S. Customs \& Border Prot., 741 F.3d 1016 (9th Cir. 2014). \\ ${ }^{66}$ See 8 C.F.R. \238.1(f)(3) ("Withholding of removal. If the alien has requested withholding of removal under $\int$
} 208.16 of this chapter, the deciding officer shall, upon issuance of a Final Administrative Removal Order, immediately refer the alien's case to an asylum officer to conduct a reasonable fear determination in accordance with $\ 208.31$ of this chapter."); 8 C.F.R. \241.8(e) (“Exception for withbolding of removal. If an alien whose prior order of removal has been reinstated under this section expresses a fear of returning to the country designated in that order, the alien shall be immediately referred to an asylum officer for an interview to determine whether the alien has a reasonable fear of persecution or torture pursuant to $\ 208.31$ of this chapter."); 8 C.F.R. $\ 235.3$ (b)(4) (“Claim of asylum or fear of persecution or torture. If an alien subject to the expedited removal provisions indicates an intention to apply for asylum, or expresses a fear of persecution or torture, or a fear of return to his or her country, the inspecting officer shall not proceed further with removal of the alien until the alien has been referred for an interview by an asylum officer in accordance with 8 CFR 208.30. The examining immigration officer shall record sufficient information in the sworn statement to establish and record that the alien has indicated such intention, fear, or concern, and to establish the alien's inadmissibility.")

${ }^{67}$ INA $235(\mathrm{~b})(1)(B)(v) ; 8$ U.S.C. $\int 1225(b)(1)(B)(v)(2014)$ ("Credible fear of persecution defined: For purposes of this subparagraph, the term 'credible fear of persecution' means that there is a significant possibility, taking into account the credibility of the statements made by the alien in support of the alien's claim and such other facts as are known to the officer, that the alien could establish eligibility for asylum . . . "); 8 C.F.R. \ 235.6 ("Referral to Immigration Judge").

68 See, e.g., 8 C.F.R. $\$ 235.6(a)(1)($ ii) (specifying that an immigration officer or asylum officer will sign and deliver a Form I-862 to an alien "if an asylum officer determines that an alien in expedited removal proceedings has a credible fear of persecution or torture and refers the case to the immigration judge for consideration of the application for asylum."); 8 C.F.R \ 208.30(f) ("Procedures for a positive credible fear finding. If an alien, other than an alien stowaway, is 
removal are instead placed into standard court proceedings accompanied with the variety of procedural safeguards described earlier.

Persons subject to administrative removal or reinstatement who indicate a fear of persecution or torture in their home country must be given a "reasonable fear" 69 interview before an asylum officer, and, if successful, are placed in a limited proceeding known as a "withholding-only" proceeding. 70 During a "withholding-only" proceeding, a person may apply for relief through a traditional form of withholding of removal and protection under the CAT. The governing statutes stipulate that individuals with a final administrative removal order or reinstatement are ineligible for any other kind of relief from removal. ${ }^{71}$ The agency has opined that, as a matter of law, the statutory prohibition on relief is consistent with the availability of withholding of removal or CAT relief because "they are merely restrictions on the place to which an alien may be removed and do not constitute affirmative permission to remain in the United States." 72

The regulations further implement these statutory bars to relief by providing that individuals in withholding-only proceedings are precluded from applying for other forms of relief from removal that might ordinarily be available to someone in regular removal proceedings, such as adjustment of status, cancellation of removal, or asylum. ${ }^{73}$ Traditional withholding of removal requires an individual to prove a clear probability of persecution by the government or an actor the government is unable or unwilling to control because of race, religion, nationality, political opinion, or membership in a particular social group. ${ }^{74}$ By contrast, the CAT requires an individual to prove a likelihood of torture by the government or with the

found to have a credible fear of persecution or torture, the asylum officer will so inform the alien and issue a Form I862, Notice to Appear, for full consideration of the asylum and withholding of removal claim in proceedings under section 240 of the Act.").

698 C.F.R. \208.31 ("Reasonable fear of persecution or torture determinations involving aliens ordered removed under section 238(b) of the Act and aliens whose removal is reinstated under section 241(a)(5) of the Act. ... The alien shall be determined to have a reasonable fear of persecution or torture if the alien establishes a reasonable possibility that he or she would be persecuted on account of his or her race, religion, nationality, membership in a particular social group or political opinion, or a reasonable possibility that he or she would be tortured in the country of removal. For purposes of the screening determination, the bars to eligibility for withholding of removal under section 241(b)(3)(B) of the Act shall not be considered ...." "). The USCIS website has a concise fact sheet on the reasonable fear screening process. See Asylum, Questions and Answers: Reasonable Fear Screening Process, U.S. CITIZENSHIP AND IMMIGRATION SERVICES, http://www.uscis.gov/humanitarian/refugees-asylum/asylum/questions-answers-reasonablefear-screenings (last updated June 18, 2013).

70 See generally 8 C.F.R. \ 208.31 ("Reasonable fear of persecution or torture determinations involving aliens ordered removed under section 238(b) of the Act and aliens whose removal is reinstated under section 241(a)(5) of the Act"); see also 8 C.F.R. $\$ 208.31$ (c) ("The alien shall be determined to have a reasonable fear of persecution or torture if the alien establishes a reasonable possibility that he or she would be persecuted on account of his or her race, religion, nationality, membership in a particular social group or political opinion, or a reasonable possibility that he or she would be tortured in the country of removal.").

71 See INA \238(b)(5), 8 U.S.C. \1228(b)(5) (2013) ("No alien described in this section shall be eligible for any relief from removal that the Attorney General may grant in the Attorney General's discretion."); INA \ 241(a)(5); 8 U.S.C. $\int 1231(a)(5)$ (2014) ("If the Attorney General finds that an alien has reentered the United States illegally after having been removed ... the prior order of removal is reinstated from its original date and is not subject to being reopened or reviewed, the alien is not eligible and may not apply for any relief under this Act, and the alien shall be removed the prior order at any time after the reentry.").

72 See Memorandum from John Torres, Acting Director for Office of Detention and Removal Operations of U.S. Immigration and Customs Enforcement to Field Office Directors, Detention and Deportation Officer's Field Manual Update, Chapter 1 (March 27, 2006) (on file with author).

73 See, e.g., 8 C.F.R. $\int 208.31$ (g)(1)(i) ("The immigration judge shall consider only the alien's application for withholding of removal under $\ 208.16$ and shall determine whether the alien's removal to the country of removal must be withheld or deferred.").

${ }^{74}$ INA \241(b)(3)(A), 8 U.S.C. \1231(b)(3)(A) (2014); 8 C.F.R \ 208.16 (2000). 
acquiescence of the government. ${ }^{75}$ Both forms of relief place the burden on an applicant to prove eligibility for relief and are adjudicated by an individual judge following an adversarial proceeding. Like with a regular immigration court proceeding, individuals in withholding-only proceedings have the right to examine and rebut evidence offered by the government, and be represented by counsel at their own expense. ${ }^{76}$ It is plausible that Congress removed the possibility for individuals subject to speed deportation programs to apply for additional relief under the theory that some people are less deserving of a full day in court. United States immigration law is comprised of staggered safeguards reflecting policy choices by Congress about who is worthy of protection. ${ }^{77}$

While the legal framework that governs noncitizens subject to reinstatement or administrative removal suggests that noncitizens who have expressed a reasonable fear may only apply for withholding of removal and relief under the CAT, there is a strong argument that such applicants can still apply for asylum. The asylum statute specifically affirms that "any alien . . irrespective of such alien's status, may apply for asylum."78 Thus, the plain text of the statute would make the limits discussed above immaterial because the statute is unambiguous that "any alien" has the right to apply for asylum. Notably, the American Immigration Lawyers Association ("AILA") and refugee rights litigants have argued, "The reinstatement regulations limiting protection from persecution to withholding of removal must be struck down . ..."79 The impact of barring asylum in this way is significant and potentially contravenes the United States' obligations under international law. ${ }^{80}$ One story featured by AILA in a related amicus brief involved "Mirabel" a woman from Honduras who was ordered removed in 2001:

Mirabel returned to Honduras where she became romantically involved with a man who became abusive after she moved in with him. He isolated and confined her to his home and raped her over and over again. He tied her up and permitted his friends to gang rape her. In one incident, after torturing her, he forced her to cook for his friends. When she did not perform to his liking, he broke a beer bottle, cut her, and beat her until she fell unconscious. After Mirabel's abuser left her for dead, she escaped to Mexico. While there, Mirabel bumped into one of her abuser's friends who had raped her. He told Mirabel that her former boyfriend was looking for her to finish the job of killing her. Mirabel then sought refuge

758 C.F.R. $\int 208.17-18$.

76 See 8 C.F.R. SS 208.31(e), 208.16; see also EXEC. OfFICE FOR IMMIGRATION REVIEW, IMMIGRATION COURT PRACTICE MANUAL 119, (2013), available at http://www.justice.gov/eoir/vll/OCIJPracManual/Practice_Manual_1-2714.pdf\#page $=119$.

${ }^{77}$ For a broader examination of other "diversions" in the immigration system, see Jill E. Family, A Broader View of the Immigration Adjudication Program, 23 GEO. IMMIGR. L.J. 595 (2009). For an analysis about narratives told about "good" immigrants versus "bad" immigrants, see Elizabeth Keyes, Beyond Saints and Sinners: Discretion and the Need for New Narratives in the U.S. Immigration System, 26 GEO. IMMIGR. L.J. 207 (2012).

78 See INA \208(a)(1), 8 U.S.C. \1158(a)(1) (2014) (emphasis added).

${ }^{79}$ Brief of Amicus for American Immigration Lawyers Association, et al., at 6, Maldonado-Lopez v. Holder (No. 12-72800), AILA InfoNet Doc. No. 13080204 (posted Feb. 8, 2013) available at http://www.aila.org/content/default.aspx?docid=45288; see also Fernandez-Vargas v. Gonzales, 548 U.S. 30 , 35 n.4 (2006) ("Notwithstanding the absolute terms in which the bar on relief is stated, even an alien subject to \$241(a)(5) may seek withholding of removal under 8 U. S. C. $\$ 1231$ (b)(3)(A) (2000 ed.) (noting that an alien may not be removed to country if “the alien's life or freedom would be threatened in that country because of the alien's race, religion, nationality, membership in a particular social group, or political opinion”), or under 8 C.F.R. \$S 241.8(e), 208.31 (raising the possibility of asylum to aliens whose removal order has been reinstated under INA \$241(a)(5))").

80 See INA \241(b)(3), 8 U.S.C. \ 1231(b)(3) (2014), which incorporates the international law principle of nonrefoulement articulated in The Convention on the Status of Refugees. See Convention Relating to the Status of Refugees Art. 33, July 8 1951, 189 U.N.T.S. 137. 
in the United States, where the Government reinstated her prior removal order. Although an asylum officer reached a positive "reasonable fear" determination, Mirabel is now in "withholding only" proceedings in which she will not even be considered for asylum. ${ }^{81}$

Although a full discussion about the differences between asylum, withholding of removal, and CAT relief are beyond the scope of this Article, it should be noted that a person granted asylum receives a more secure status, the ability to include their spouse and children as derivatives, and the possibility to eventually obtain lawful permanent residence (green card) and citizenship. ${ }^{82}$ None of these benefits are available to a person who is granted withholding of removal or CAT. Likewise, the BIA has articulated that a grant of withholding of removal requires an explicit order of removal, further indicating that, as a legal matter, this form of protection operates as a restriction on where a person may be removed and not as permission to remain in the United States indefinitely. ${ }^{83}$

Statistics from the EOIR are not entirely clear about the number of regular removal proceedings that originated from the expedited removal process but reveal that immigration courts received 2,269 withholding-only ${ }^{84}$ proceedings in fiscal year 2013.85 Again, these proceedings refer to those individuals who were found to have a "reasonable fear of persecution or torture" by the asylum officer or the immigration judge (following an appeal of a negative reasonable fear finding by the asylum officer) after an administrative removal order or reinstatement order.

While withholding-only hearings make up only a small fraction of the overall caseload untaken by EOIR each year, the growth of such hearings is notable. According to the EOIR Statistical Yearbook for 2013, the immigration court received 240 withholding-only proceedings in 2009, 497 proceedings in 2010, 886 proceedings in 2011, 1,090 proceedings in 2012, and 2,269 proceedings in 2013.86 On the one hand,

${ }^{81}$ Brief of Amicus for American Immigration Lawyers Association, et al., supra note 79, at 1-2.

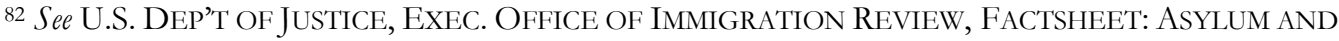
WithHolding of Removal Relief Convention Against TORTURE Protections, 6 (2009), available at http://www.justice.gov/eoir/press/09/AsylumWithholdingCATProtections.pdf.

83 See Matter of I-S- \& C-S-, 24 I. \& N. Dec. 432 (BIA 2008) ("When an Immigration Judge issues a decision granting an alien's application for withholding of removal under section 241(b)(3) of the Immigration and Nationality Act, 8 U.S.C. \ 1231(b)(3) (2000), without a grant of asylum, the decision must include an explicit order of removal.”); see also U.S. DeP’T OF JUSTICE EXEC. OfFICE OF IMMIGRATION REVIEW, EOIR Benchbook. Alert (2008), available at http://www.justice.gov/eoir/vll/benchbook/alerts/alert_wr.htm.

${ }^{84}$ For statistical purposes, EOIR considers "withholding only proceedings" as part of the overall "immigration matters" it handles in a given fiscal year. See, e.g., OfFICE OF LEGISLATIVE AND PUBLIC AFFAIRS, FY2012 STATISTICAL YEARBOOK, EXECUTIVE OFFICE OF IMMIGRATION REVIEW C2-C3 (2013), available at http://www.justice.gov/eoir/statspub/fy12syb.pdf. Likewise, the EOIR statistical yearbook for 2012 states "A withholding only hearing is initiated when the following conditions have been met:

- A previous removal/deportation/exclusion order has been reinstated by DHS or the alien has been ordered removed (administratively) by DHS (based upon a conviction for an aggravated felony) and the alien expresses a fear of persecution or torture if returned to the country of removal and that claim is reviewed by an asylum officer, and

- An asylum officer has concluded that the alien has a reasonable fear of persecution or torture or an immigration judge conducted a reasonable fear review proceeding and found that reasonable fear of persecution or torture exists, OR

- An alien who is an applicant for admission to Guam or the Commonwealth of the Northern Mariana Islands (CNMI) under the Guam-CNMI Visa Waiver Program under section 212(i) of the Immigration and Nationality Act or who was admitted to Guam or the CNMI under the Guam-CNMI Visa Waiver Program and has violated their conditions of admission is subject to withholding only proceedings prior to January 1, 2015.”

85 U.S. DEP’T OF JUSTICE EXEC. OfFICE FOR IMMIGRATION REVIEW, FY 2013 STATISTICAL YEARBOOK B1 (2014), available at http://www.justice.gov/eoir/statspub/fy13syb.pdf.

${ }^{86} \mathrm{Id}$. 
the growth in numbers may indicate that DHS is doing a better job at screening people subject to reinstatement or administrative removal who express a fear of persecution or torture, or that more people in these categories have facts that are more likely to lead to a reasonable fear finding. On the other hand, and more likely given the trend of increased speed deportations, the growth in withholding-only hearings may be tied to the growth in reinstatements and administrative removals by DHS. This growth in reinstatements and administrative removals may be associated with a change of policy, under which DHS will now divert into a speed removal program people who might have ordinarily been issued a Notice to Appear and placed in removal proceedings before an immigration judge. Whether this increase in withholding-only hearings is unlawful may be hard to pin down as "arbitrary." People with similar facts and backgrounds can just as easily be given a formal 240 removal hearing or instead, be placed in a truncated withholding-only proceeding after being ordered removed and then passing a reasonable fear interview. Perhaps the growth reflects a policy choice by DHS to effectuate removals with more efficiency and reach a certain number of removals. The next section examines the policy and politics of these programs in more detail.

\section{The Policy and Politics of Speed Deportation}

To examine the legitimacy of speed deportation programs as a policy matter, this section considers 1) the personal interest of the noncitizen subject to speed deportation; 2) the risk of error, and value of additional procedural safeguards; and 3) the government's interest, including the fiscal and administrative burdens of more procedures. ${ }^{87}$

\section{A. Personal Interests Affected by Deportation}

Some might take a position that the personal interests are low in the case of a first-time visitor to the United States facing expedited removal. Likewise, some may argue that individuals who enter the United States without inspection or after a previous removal (reinstatement) are not entitled to personal ties to the United States because they have violated the law. ${ }^{88}$ Moreover, others may argue that since administrative removal is aimed at persons who are not lawful permanent residents of the United States and who have been found to have an aggravated felony conviction, the interest is low. But these positions are less attractive if a person is fleeing persecution or torture, entering the United States to reunite with a family member, or otherwise eligible for relief from removal. As a policy matter, my view is that personal interests should not be measured by a person's manner of entry, immigration status, or even criminal history as the individual stakes of nonjudicial deportation are all too high.

The human consequences of speed deportation cannot be underestimated. It can result in the forced expulsion of people who bear strong equities like tender age, community ties, intellectual promise, and family members who are United States citizens. The legal framework that governs speed removal does not contain exceptions for individuals who have other equities or even eligibility for a benefit like adjustment of status through marriage to a United States citizen or sponsorship by a United States employer. Imagine the case of Eduardo, an undocumented worker from Chile who enters the United States as a student at University X, violates the term of his visa by working without authorization, and is convicted once for a misdemeanor crime that qualifies as an "aggravated felony." Thereafter, Eduardo meets and falls in love with a friend from University X who was born in the United States and, together, they decide to marry in a church ceremony. Eduardo is viewed as a caring father and husband and

${ }^{87}$ This section loosely follows the due process balancing test/standard set up in Matthew v. Eldridge, 424 U.S. 319 (1976) for considering the policy and politics of speed deportation but it should be noted that the author does not intend to use Mathews to question the constitutionality of speed deportation programs.

88 David A. Martin, Two Cheers for Expedited Removal, 40 VA. J. OF INT’L. L. 673, 690 (2000). 
volunteer in his community. Under the immigration law, Eduardo can be arrested and placed in "administrative removal" based on his criminal history and then removed within 14 days of the final removal order. ${ }^{89}$ The administrative removal scheme does not exempt people like Eduardo who are married to a United States citizen or a father to a United States citizen. The troubling aspect of this statutory scheme is two-fold: it prevents Eduardo from seeing an immigration judge or undergoing removal proceedings before he is removed, and it categorically bars him from any immigration relief for which he might otherwise qualify, such as adjustment of status.

As was analyzed earlier in the context of the administrative removal statute, the reinstatement statute prevents individuals, thousands of whom may have no criminal history at all, from seeking relief before an immigration judge. The act of someone leaving the United States after a removal order and then coming back into the United States without admission might be grave enough to make the reinstatement sound reasonable. The challenge is that these same individuals may be otherwise law-abiding but still choose to enter unlawfully in order to reunite with their family, flee from persecution, leave a poverty state, or access medical care for a serious condition. Individuals who bear these equities should have the opportunity to present them to an immigration judge — as opposed to a DHS officer—and apply for relief for which they are eligible (based on these equities) before deportation.

\section{B. Risk of Error and Value of Additional Safeguards}

This section explores the possibility that DHS will erroneously place a person in a speed deportation program and the extent to which adding safeguards would reduce this error. These errors can take many forms. For example, if DHS mistakenly executes an expedited removal order to a lawful permanent resident or issues an administrative removal order to a noncitizen who was convicted of a crime that does not qualify as an aggravated felony. If there is a significant risk of error under the existing framework, the next question is whether additional procedural safeguards can prevent or minimize this risk. The existing statutory and regulatory framework arguably contains enough process to minimize the risk of error. If adding more procedure does not reduce the risk of erroneous deportation, there may be room to argue that speed deportation programs should be dissolved altogether.90

\section{Agency Expertise}

Related to the analysis about the possibility for mistakenly placing people in speed deportation is whether DHS has the proficiency to screen and determine that a person is legally subject to speed deportation. Arguably, if DHS lacks the expertise to make determinations associated with expedited removal, reinstatement, or administrative removal, the risk of error is greater. To illustrate, DHS may issue an expedited removal order to any noncitizen who arrives without documentation or with false documentation if he or she expresses a fear of return based on persecution or torture. ${ }^{91}$ While officers of DHS are trained to assess verbal and behavioral cues that might indicate a person may fear harm in her home country, only a small percentage of individuals subject to expedited removal are referred to an asylum officer for a credible fear interview. According to DHS, "From FY 2000 through FY 2009, the annual percentage of individuals subject to expedited removal who expressed a fear of return ranged from 4-6\%.

898 CFR \1238.1(f)(1) (2003) ("Upon the issuance of a Final Administrative Removal Order, the Service shall issue a Warrant of Removal in accordance with $\$ 1241.2$ of this chapter; such warrant shall be executed no sooner than 14 calendar days after the date the Final Administrative Removal Order is issued, unless the alien knowingly, voluntarily, and in writing waives the 14-day period.").

90 On the other hand, one may argue that such programs need not be perfect to be rational and that mistakenly removing some people in order to operate a streamlined deportation program is a legitimate end.

91 See INA \238(b), 8 U.S.C. \1228(b) (2013). 
From FY 2010 through FY 2012, the annual percentage ranged from 7-9\%."’92 The low rate of referrals may be tied to the actual number of arriving noncitizens who qualify for referral to an asylum officer for a credible fear interview. But a second possibility is that DHS is turning away legitimate asylum seekers because of a lack of information or expertise to assess the cues appropriate for such referral. One study from 2005 conducted by the United States Commission for International Religion Freedom found that in "nearly 15 percent of the cases which Study experts observed directly and in person, asylum seekers who expressed a fear of return were nevertheless removed without a referral to an Asylum Officer. Of those cases, nearly half of the files indicated that the asylum seeker had not expressed any fear." 93 More recently, American Immigration Council published a report detailing the state of credible fear and asylum procedures, and reported, "We heard frequent complains that CBP officers often dissuade people from seeking asylum, sometimes berating and yelling at them. Some advocates complained that clients were harassed, threatened with separation from their families or long detentions, or told that their fears did not amount to asylum claims." 94 According to one Florida non-profit attorney featured in the Council's report, “CBP doesn't do its job and ask the right questions about fear of return. People are removed under expedited removal and then come right back because they are afraid. Then they are only eligible for a reasonable fear interview and withholding of removal and detained for a long time." 95 This anecdote sheds light not only on the possibility that CBP may erroneously deport noncitizens instead of making referrals to asylum officers for credible fear interviews, but also displays how the different speed deportation programs interact with one another. In the aforementioned example, individuals are initially issued an expedited removal order, and, upon return, may qualify only for a reasonable fear interview because they are then subject to a reinstated order. As a final illustration of public concern around the referral process, the American Immigration Lawyers Association (AILA) circulated a survey to its membership soliciting examples of "individuals who were apprehended by CBP after crossing into the U.S. and issued expedited removal orders without the opportunity for a credible fear interview when the individual clearly expressed fear to the officer or was not asked about a fear of return at all." 96 Presumably, this survey suggests dissatisfaction with the quality of CBP's screening process for genuine refugees who face expedited removal. There is less concrete evidence about the quality of DHS referrals of noncitizens reinstatement or administrative removal orders to an asylum officer after they express a fear of persecution or torture. Part of the ambiguity is tied to the practical reality that many pro bono attorneys do not interface with this population until after they have passed their reasonable fear interviews. ${ }^{97}$

To offer a second example about the experience level of DHS officers who make removal decisions, the regulations that govern reinstatement of removal permit DHS to summarily remove "[a]n alien who illegally reenters the United States after having been removed, or having departed voluntarily,

\footnotetext{
92 Asylum Abuse: Is It Overwhelming Our Borders?: Hearing Before the H. Comm. on the Judiciary, 113th Cong. 39 (written testimony of USCIS Deputy Director Scialabba, ICE Deputy Director Daniel Ragsdale, CBP Office of Border Patrol Chief Michael Fisher).

93 UNITED STATES COMM’N ON INT’L RELIGIOUS FREEDOM, EXPEDITED REMOVAL REPORT CARD: 2 YEARS LATER 4 (2007), available at http://www.uscirf.gov/sites/default/files/resources/stories/pdf/scorecard_final.pdf.

94 SARa CAMPOS \& JOAN Friedland, MEXiCAN AND CENTRAl AMERICAN ASYlum AND CREDIBLE FEAR CLAIMS: BACKGROUND AND CONTEXT 10 (May 21, 2014), available at http://www.americanimmigrationcouncil.org/sites/default/files/docs/asylum_and_credible_fear_claims_final.pdf. 95 Id. at 10.

96 AIL A Seeks Examples of CBP Denying Individuals Access to Credible Fear Interviews, AILA INFONET, http://www.aila.org/content/default.aspx?docid=484114 (last visited May 16, 2014).

${ }^{97}$ Florence ImMigrant \& RefugeE Rights Project, Guide to Credible \& REASOnABle FEAR PROCEEDINGS 5 (2013), available at http://www.firrp.org/media/CF-RF-Guide-2013.pdf (noting that "[i]f you are waiting for a credible or reasonable fear interview you will probably not see the Florence Project until you pass and are waiting for your first hearing.”).
} 
while under an order . . .."98 However, the question of whether an entry is "lawful" or whether the procedural safeguards spelled out in the regulations are being followed are legally complex and may indicate that trained judges are better suited to analyze each element of the reinstatement statute. In one case, Cardova-Soto v. Holder, a federal judge found that a noncitizen who returned to the United States following a removal order as a backseat passenger in a taxi after presenting herself at the port-of-entry was still making an "illegal entry" for reinstatement purposes. ${ }^{99}$ Cardova-Soto entered the United States as an infant and eventually became a lawful permanent resident at the age of 13 . She worked in fast food restaurants in order to support her family and eventually received a high school degree equivalent. Because of her prior conviction for drug possession, however, she was placed in removal proceedings and ordered to be removed based on this activity through a stipulated order of removal. Cardova-Soto returned to the United States without authorization in order to reunite with her four United States citizen children and her husband, also a United States citizen.100 While the court ultimately found that reinstatement applied, it analyzed a body of case law before making a determination that the reinstatement statute could be applied to a procedurally regular entry. ${ }^{101}$

As a third example, errors can take place during the administrative removal process. To recap, administrative removal applies to individuals who are neither citizens nor green card holders and have been convicted of an aggravated felony. ${ }^{102}$ In other words, administrative removal applies to someone who is in the United States with a temporary or undocumented status and has a criminal history. While the aggravated felony list is a broad one, the analysis is complicated by the fact that state, federal, and foreign offenses may qualify as "aggravated felonies." Importantly, an officer or judge cannot make a decision about whether a criminal conviction qualifies for deportation without analyzing the statute under which the noncitizen was convicted. Under the "categorical approach," adjudicators are to look "not to the facts of the particular prior case," but instead to whether "the state statute defining the crime of conviction" categorically fits within the "generic" federal definition of a corresponding aggravated felony. ${ }^{103}$ Even immigration judges, BIA members, and federal court judges reach legally questionable conclusions that in several cases have resulted in a reversal by the United States Supreme Court. ${ }^{104}$ For example, in Moncrieffe v. Holder, the Supreme Court reversed the Fifth Circuit and the BIA and found that a conviction for marijuana possession with intent to distribute under a Georgia statute may not be deemed a drug trafficking aggravated felony for immigration purposes. ${ }^{105}$ In reaching this conclusion, the Court compared the elements of the Georgia statute with the Controlled Substance Act, the federal statute referenced in the aggravated felony definition for drug trafficking. Because the Georgia statute is broad

98 See 8 C.F.R. $\int 241.8$ (a).

99732 F.3d 789 (7th Cir. 2013).

100 See id.

${ }^{101} \mathrm{Id}$. For an analysis of the Cordova-Soto case and how the reinstatement of removal order stemmed from a stipulated removal order, see Jennifer Lee Koh, Rethinking Removability, 64 FLA. L. REV. 1803, 1864-18667 (2014).

102 See INA \238(b)(1), 8 U.S.C. \ 1449(b)(1) (1952).

103 Taylor v. United States, 495 U.S. 575, 599-600 (1990); Descamps v. United States, 133 S. Ct. 2276 (2013).

104 See, e.g., Moncrieffe v. Holder, 133 S. Ct. 1678 (2013) (holding that possession with intent to distribute was not necessarily a felony because a conviction under state law did not consider possible exceptions for small amounts of marijuana possessed without remuneration); Carachuri-Rosendo v. Holder, 550 U.S. 563 (2010) (holding that a second conviction for simple possession could not be an aggravated felony because the noncitizen was charged with a misdemeanor under state law and it was inappropriate for immigration courts to enhance the conviction ex post facto); Watson v. U.S., 552 U.S. 74 (2007) (holding that under a plain English reading of the law, a noncitizen who traded drugs for a gun could not be convicted of a felony for "using" a gun during a drug trafficking crime); Lopez v. Gonzalez, 549 U.S. 47 (2006) (determining that a drug offense that was a felony under state law but only a misdemeanor under federal law was not an aggravated felony); Leocal v. Ashcroft, 543 U.S. 1 (2004) (finding that because state law classified DUIs as having a mens rea of negligence or less, it was inappropriate for the lower court to classify those DUIs as "crimes of violence", and thereby find the noncitizen guilty of an aggravated felony).

105 Moncrieffe, 133 S. Ct. 1678. 
enough to punish conduct involving a small amount of marijuana for no remuneration, the Court reasoned that it could not qualify as an aggravated felony as the Controlled Substance Act contains an "exception" for cases involving a small amount and no remuneration. Arguably, and as a result of Moncrieffe, anyone administratively removed pursuant to a state conviction similar to the Georgia statute in which there is an element of "possession with intent to distribute" but no element of remuneration or any minimum quantity of marijuana may not qualify as an aggravated felon. ${ }^{106}$ Thus, an important question is whether the DHS, as opposed to a judge, should determine whether a person is an aggravated felon. The examples above illustrate the complex analysis involved in applying expedited removal, reinstatement, and administrative removal, and also raise legitimate concerns about sustaining a paradigm in which people can be removed without any process or regular court proceeding.

As a final example, it is possible that speed deportation programs, where the screening is limited and the deportation timeline immediate, increase the chances that DHS will mistakenly deport a United States citizen. Scholars have identified the legal and factual complication of citizenship, especially when one is claiming derivative citizenship, citizenship by acquisition, or when one does not know he has a claim to citizenship. ${ }^{107}$ The possibility of error is higher when this complexity is combined with speed. Professor Lee Terán describes the wrongful deportation of Wilfredo Garza, the son of a United States citizen who raised a citizenship claim to DHS:

Mr. Garza filed an application for certificate of citizenship to DHS, and he repeatedly told the officer that he had a claim to citizenship. DHS failed to consider Mr. Garza's claim and simply removed him. The risk of removal of individuals with citizenship claims is high when examination by DHS is limited to the identity of the individual subject to reinstatement and whether he has previously been deported or removed. The procedures implemented by DHS fail to require at a minimum a full and objective investigation of the claim, cancellation of the reinstatement order, and referral to the immigration judge. The unbridled use of INA Section 241(a)(5) under procedures where there is no hearing before an immigration judge and no meaningful opportunity to present a claim to citizenship all but guarantees that individuals like Mr. Garza who have unresolved claims to U.S. citizenship are removed. 108

\section{The Government's Interest}

\section{Improving Efficiency}

The policy goals of accelerating deportation for select populations are partially economic. In describing the cost-savings associated with the expedited removal program, former INS General Counsel David Martin noted, "The ER process allows INS to issue formal removal orders even more efficiently, particularly where asylum is not at issue ... [ER] takes a matter of hours rather than days, and in the overwhelming majority of such cases, as before, there is no genuine issue about whether fraud has been

106 See AMERICAN IMmigration COUNCIL ET. AL., MONCRIEFFE V. HOLDER: IMPLiCATIONS FOR DrUG CHARGES AND OTHER Issues INVOLVING THE CATEGORICAL APPROACH 6-7 (May 2, 2013), available at http://immigrantdefenseproject.org/wp-content/uploads/2013/05/Moncrieffe-PA-5-1-13-FINAL.pdf.

107 See generally Jacqueline Stevens, U.S. Government Unlawfully Detaining and Deporting U.S. Citizens as Aliens, 18 VA. J. SOC. POL'Y \& L. 637 (2011); see also Koh, supra note 101 (describing the complexity of U.S. citizenship claims and the large numbers of U.S. citizens have been subject to immigration enforcement).

${ }^{108}$ Lee. J Terán, Mexican Children of U.S. Citizens: "Vignes Prin" and Other Tales of Challenges to Asserting Acquired U.S. Citizenship, 14 SCHOLAR 583, 662-63 (2012). 
attempted."109 Accelerating removal through programs like administrative, expedited, and reinstatement removal improves economic efficiency. Such removals avoid the costs associated with an administrative hearing before the immigration judge, time from the DHS trial attorney, an interpreter, law clerk, transcriber, and future appeals. Indeed, EOIR statistics are staggering as immigration judges handle thousands of matters each year. ${ }^{110}$ The crisis faced by immigration courts persist and as stated in a frontpage story that ran in The Washington Post in February 2014:

[D]ay after day, case after case, in one of the 57 overwhelmed immigration courts across the country. Here, on the second floor of a high rise in Crystal City, tissue boxes are stacked near the courtroom entrance and attorneys push rolling file cabinets, because a briefcase is no longer sufficient to hold caseloads that have tripled in the past decade. ${ }^{111}$

Described by one immigration judge as "doing death penalty cases in traffic court" the job of an immigration judge is stressful:

Tough was hearing 1,500 cases per year while federal judges decided 440. It was sharing one law clerk with other immigration judges while each federal judge had four clerks of his own. It was being scheduled to sit on the bench for 36 hours a week and listen to asylum cases that detailed people's escapes from gangs, rapes, beheadings, human trafficking and torture; and then having to objectively ask those people for the documents, for the scars, for the proof; and then making a judgment about the character of those people, first through a video feed and then through an interpreter; and then judging the merits of their cases in the shifting landscape of immigration law; and finally taking a deep breath, synthesizing so much information, and rendering a lawful, smart, artful, confident decision on the spot, because the schedule allowed little time for reflection or written decisions before the next case began. ${ }^{112}$

The tension faced in immigration courts was heightened by a furlough of the federal government in 2013, which set the court backlog back even further. As described in one related news account: "Immigration Judge Dana Leigh Marks said she doesn't have two weeks open on her calendar in San Francisco's immigration court for merit hearings until June 2017. And she can't just bump people with court dates this year, because they've also been waiting for their day in court." 113 If people who are placed in removal

\footnotetext{
${ }_{109}$ Martin, supra note 88.

${ }^{110}$ EOIR Statistics for 2012 reveals that that the immigration courts completed 382,675 matters. OFFICE OF Planning, ANAlysis, \& TeChNOlOgy, ExeC. OfFICE OF IMMIGRATIOn REVIEW, FY2012 StATISTICAL YEARBOOK B2 (2013), available at http://www.justice.gov/eoir/statspub/fy12syb.pdf. According to TRAC, as of January 2014, the number of pending deportation cases was at an all-time high of 360,186. Backlog of Pending Cases in Immigration Courts as of January 2014, TRACIMMIGRATION, http://trac.syr.edu/phptools/immigration/court_backlog/apprep_backlog.php (last visited Mar. 10, 2014).

111 Eli Saslow, In a Crowded Immigration Court, Seven Minutes to Decide a Family's Future, THE WASHINGTON POST (Feb. 2, 2014), http://www.washingtonpost.com/national/in-a-crowded-immigration-court-seven-minutes-to-decide-afamilys-future/2014/02/02/518c3e3e-8798-11e3-a5bd-844629433ba3_story.html.

$112 \mathrm{Id}$.

113 Amy Taxin, Government Shutdown Hurt More Than 37,000 Immigration Cases, Huffington PosT (Feb. 22, 2014, 12:47 PM), http://www.huffingtonpost.com/2014/02/22/government-shutdown-immigration_n_4838375.html. In 2013, the average number of days a pending case had been open was 760 days; in January 2014, the average was 809 days. Backlog of Pending Cases in Immigration Courts as of January 2014, supra note 110; see also Daniel M. Kowalski, 555-Day Backlog at Houston Immigration Court, LEXISNEXIS NEWSROOM, IMMIGRATION LAW (Dec. 24, 2013, 9:21AM),
} 
proceedings are waiting for up to two years to be scheduled for a trial or what is commonly called the "individual calendar hearing,"114 then what kind of resources would be needed to provide such hearings for individuals who are currently processed through a speed deportation program?

Proponents of speed deportation also may view it as an efficient deterrent for stemming unlawful migration into the United States. ${ }^{115}$ Arguably, a Mexican national who is considering re-entry into the United States following a removal order may be deterred from doing so based on his knowledge of the reinstatement statute and the fact that he can be removed without consideration of his equities like a United States citizen child. But speed removal programs are not effective as deterrents if people have compelling reasons to be in the United States. For example, reunification with a family or prospect of steady employment are factors that often propel migration in spite of the related risks. Likewise, it is hard to confirm if individuals potentially at risk for speed deportation have knowledge about these programs and the consequences that follow. Nevertheless, the literature on unauthorized migration suggests that people come to the United States for opportunity and in spite of the risks of potential deportation. ${ }^{116}$ Beyond the scope of this Article but critical to understanding the root causes for migration is the wave of families and unaccompanied minors entering the United States from Central America. Social scientists, legal experts and the United Nations have identified violence, not poverty, as a key driver for this migration wave. ${ }^{117}$

\section{Enforcement Mission}

Another important policy question is the degree to which speed removal programs support the mission of DHS. According to its website, ICE's primary mission is to "promote homeland security and public safety through the criminal and civil enforcement of federal laws governing border control, customs, trade and immigration."118 Higher deportation numbers also benefit the image the government seeks to portray to the policymakers who support amplified immigration enforcement. As described in the press release by DHS in connection with its 2013 removals:

These figures highlight ICE's ongoing commitment to primary immigration enforcement missions: the apprehension of criminal aliens

http://www.lexisnexis.com/legalnewsroom/immigration/b/outsidenews/archive/2013/12/24/555-day-backlog-athouston-immigration-court.aspx; AMERICAN BAR ASSOCIATION, COMMISSION ON IMMIGRATION, REFORMING THE IMMigRATION SYSTEM: Proposals to Promote INDEPENDENCE, FAIRNESS, EFFICIENCY, AND PROFESSIONALISM IN THE ADJUDICATION OF IMMIGRATION CASES (2010), available at http://www.americanbar.org/content/dam/aba/migrated/Immigration/PublicDocuments/aba_complete_full_report.a uthcheckdam.pdf.

114 Introduction to THE Master CALENDAR, U.S. DeP’T OF JUSTICE EXECUTIVE OfFiCE OF

IMMIGRATION REVIEW, IMMIGRATION JUDGE BENCHBOOK, available at

http://www.justice.gov/eoir/vll/benchbook/tools/Purpose_and_History_of_MC.pdf (last visited Feb. 25, 2014).

115 See, e.g., Alison Siskin \& Ruth Ellen Wasem, Cong. Research Serv., RL 33109, Immigration

POLICY ON EXPEDITED REMOVAL OF ALIENS 15 (2005), available at

http://fpc.state.gov/documents/organization/54512.pdf ("In addition, there is evidence that the most recent expansion of expedited removal along the southwest border has decreased the apprehensions of OTMs along the border,72 which may imply that the expansion of expedited removal has been a deterrent to those trying to enter the country illegally").

116 See, e.g., Chiamaka Nwosu et. al., Frequently Requested Statistics on Immigrants and Immigration in the United States, MigRATION POLICY INSTITUTE (Apr. 28, 2014), http://www.migrationpolicy.org/article/frequently-requested-statisticsimmigrants-and-immigration-united-states.

117 See, e.g., Sonia Nazario, The Children of the Drug Wars, A Refugee Crisis, Not an Immigration Crisis, N. Y. TIMES

(July 11, 2014), http://www.nytimes.com/2014/07/13/opinion/sunday/a-refugee-crisis-not-an-immigration-

crisis.html?_r=0.

118 Overview, ICE, http:/ /www.ice.gov/about/overview/ (last visited Mar. 29, 2014). 
and other immigration violators in the interior of the United States; and the detention and removal of individuals apprehended by ICE and U.S. Customs and Border Protection (CBP) while attempting to unlawfully enter the United States. ${ }^{119}$

ICE linked the removal numbers to the agency's commitment to enforcement and the surge in removals involving an identified "priority," 120 but advocates for immigration reform were critical of the continued deportation apparatus and fact that some people deported might in the future qualify for a legalization program. ${ }^{121}$ Likewise, immigration advocates have been wary about how DHS defines a "priority", especially as "recent illegal entrants" and "aliens who are fugitives or otherwise obstruct immigration controls" are deemed to be "priorities" for enforcement even though many people who fall into these categories lack a criminal background or history that ordinary people would calculate as serious. ${ }^{122}$ Criticism over DHS's removal record has been directed not only at DHS, the agency responsible for executing removal orders, but also at the Obama administration. At the annual awards dinner of the National Council of La Raza, its president, Janet Murgia, labeled President Barack Obama as the "deporterin-chief." 123 At the same dinner, Democratic Senator Robert Menendez remarked, "While we continue waiting for the House of Representatives to wake up and move on immigration reform legislation, I urge the President to take action today and halt needless deportations that are splitting apart our families and communities."124 Even before ICE released its removal numbers for 2013, policy think tanks and journalists wrote fierce headlines highlighting that President Obama has deported more noncitizens each year than were deported during the entirety of the George W. Bush administration. ${ }^{125}$ While one may conclude that DHS has utilized speed deportations in order to keep their removal statistics high for political reasons, the merits of this choice may not be as simple and are worthy of debate.

In March 2014, President Obama indicated that DHS would review its deportation numbers and he emphasized his "deep concern about the pain too many families feel from the separation that comes from our broken immigration system." 126 Thereafter, members of the media, members of Congress, and advocates published ideas and recommendations for modifying the current deportation policy. Indeed, the "government interest" behind speed deportation is further complicated by efficient removal of priority subjects on the one hand and protecting family members and others with equities from removal on the

${ }^{119} \mathrm{Id}$.

120 See Memorandum from Morton, supra note 14; see also WADHIA, supra note 18.

121 See, e.g., Walter Ewing, New ICE Deportation Statistics Are No Cause for Celebration, Immigration ImPACT (Dec. 20, 2013), http://immigrationimpact.com/2013/12/20/new-ice-deportation-statistics-are-no-cause-for-celebration/.

122 See Memorandum from Morton, supra note 14; see also Maria Ines Zamudio, Felony Deportation Decline as ICE

Officers Resist Former Chief's 2010 Directive, THE CHICAGO REPORTER (Oct. 30, 2013),

http://www.chicagoreporter.com/ felony-deportations-decline-ice-officers-resist-former-chiefs-2010-directive.

${ }^{123}$ Justin Sink, Obama Rebukes Deportation Criticism, THE HILl (Mar. 6, 2014, 12:30 pm),

http://thehill.com/blogs/blog-briefing-room/200106-obama-rebukes-deportation-criticism.

${ }^{124}$ Alexander Bolton, Dems to Obama: Slow the Deportations, THE HiLl (June 6, 2014, 6:00 am),

http://thehill.com/homenews/senate/200066-dems-to-obama-slow-the-deportations.

125 See, e.g., Ana Gonzalez-Barrera and Mark Hugo Lopez, High rate of deportations continue under Obama despite

Latino disapproval, PEW RESEARCH CENTER FACT TANK (Sept. 19, 2013), http://www.pewresearch.org/fact-

tank/2013/09/19/high-rate-of-deportations-continue-under-obama-despite-latino-disapproval/.

126 Press Briefing, Press Secretary Jay Carney \& Secretary of Education Arne Duncan (March 14, 2014)

(available online at http://www.whitehouse.gov/photos-and-video/video/2014/03/14/press-briefing); see also, Michael D. Shear, Obama Orders Review of Deportations, N. Y. Times (Mar. 13, 2014),

http://www.nytimes.com/2014/03/14/us/obama-orders-review-of-deportations.html; Michael D. Shear \& Julia

Preston, Deportation Policy Shift is Signaled by Obama, N.Y. Times (Mar. 14, 2014),

http://www.nytimes.com/2014/03/15/us/politics/deportation-policy-shift-is-signaled-by-

obama.html?hpw\&rref=politics\&_r=0. 
other hand, and makes it that much more difficult to clarify. Nevertheless, creating an enforcement policy that is also humane is part of the mission of DHS. In discussing how expedited removal in particular is tied to a broader enforcement strategy, Professor David Martin argues:

It makes sense to concentrate immigration enforcement at the border. As a general matter, catching violators during the first attempt at entry prevents inadmissible aliens from establishing homes, employment, and other ties to this country. This enforcement strategy also makes it easier for the individual involved to resume their lives in their countries of origin. ${ }^{127}$

Though Professor Martin's view was provided in the context of expedited removals only, it raises a policy question for this Article about whether first-time violators with an expedited removal order are distinguishable from other subjects of speed deportation who have the kinds of equities and hardships showcased by immigration advocates. Certainly, and as identified earlier, there remains the possibility for one person to interact with more than one type of speed deportation program by, for example, entering the United States without documents and then getting ejected through expedited removal and by reentering the United States years later only to face a reinstatement order regardless of equities.

\section{The Relationship Between Discretion and SpeEd Deportation}

DHS has discretion in deciding whether to subject an individual to speed deportation. ${ }^{128}$ Individuals who have equities (such as a spouse who is a United States citizen) a serious medical disability, or eligibility for formal relief should be given a full court proceeding and the opportunity to apply for relief from removal that they may otherwise be prohibited from seeking. The premise that DHS can exercise discretion by placing such individuals in removal proceedings before an immigration judge (as opposed to a speedy one) is established in the statute, case law, general principles of prosecutorial discretion, agency memoranda, and secondary treatises. ${ }^{129}$ "Prosecutorial discretion" refers to a decision by the immigration agency about whether, and to what extent, the DHS should enforce immigration laws against a person or group.

Broad authority for prosecutorial discretion can be found in Section 103 of the INA, which affirms that DHS "[is] charged with the administration and enforcement of this Act and all other laws relating to the immigration and naturalization of aliens."130 The Supreme Court has also recognized the legality of prosecutorial discretion in the immigration context. In the case Arizona v. United States, the Court wrote, "Removal is a civil matter, and one of its principal features is the broad discretion exercised by immigration officials, who must decide whether to pursue removal at all." 131 Such discretion is also supported by the language of the statute and case law specific to reinstatement, expedited removal, and administrative removal. In the reinstatement context, the Ninth Circuit found that "Even though an alien is not entitled to a hearing before an immigration judge on the issue of reinstatement of a prior removal order, nothing in [the statute] or its implementing regulations deprives the agency of discretion to afford an alien a new plenary removal hearing." 132 Citing to the wide prosecutorial discretion held by DHS, the court continued:

${ }^{127}$ Martin, supra note 90, at 687.

128 See generally Memorandum from Morton, supra note 14.

129 See, e.g., \INA 238(b)(1), 8 U.S.C. \1238(b) (1) (2014); Memorandum from Morton, supra note 14; Memorandum from William J. Howard, Principal Legal Advisor, U.S. Immigration \& Customs Enforcement 3 (Oct. 24, 2005) available at http://www.aila.org/content/default.aspx?bc $=1016 \% 7 \mathrm{C} 6715 \% 7 \mathrm{C} 8412 \% 7 \mathrm{C} 18465 \% 7 \mathrm{C} 17718$.

130 INA \103(a)(1), 8 U.S.C $\$ 1103(a)(1)(2014)$.

131132 S. Ct. 2492 (2012).

132 Villa-Anguiano v. Attorney General, 727 F.3d 873, 878 (2013). 
Particularly when there is any question about whether the requirements of 241.5 [sic] have been satisfied and even they have been, an ICE officer may decide to forgo reinstatement of a prior order of removal in favor of initiating new removal proceedings with accompanying procedural rights to counsel and a hearing in immigration court.133

In the administrative removal context, the statute explicitly gives DHS a choice to place a person in speed deportation or 240 removal proceedings. Specially, Section 238(b)(1) of the INA states that the [Secretary of Homeland Security] "[M]ay, in the case of an alien described in paragraph (2) [relating to nonLPRS] determine the deportability of such alien under section 237(a)(2)(A)(iii) and issue an order of removal pursuant to the procedures set forth in this subsection or section 240."134 The language of the statute leaves open the possibility that DHS has prosecutorial discretion to place a person legally subject to 238(b) before a trier of fact in a 240 removal proceeding.

Likewise, in the expedited removal context, the BIA held that INA $\$ 235(\mathrm{~b})(1)(\mathrm{A})(\mathrm{i})$ does not limit the prosecutorial discretion of DHS to place "arriving aliens" in removal proceedings under section 240 of the Act. ${ }^{135}$ Notably, the Board held:

First, we observe that the issue arises in the context of a purported restraint on the DHS's exercise of its prosecutorial discretion. In that context, we find that Congress' use of the term "shall" in section 235(b)(1)(A)(i) of the Act does not carry its ordinary meaning, namely, that an act is mandatory. It is common for the term "shall" to mean "may" when it relates to decisions made by the Executive Branch of the Government on whether to charge an individual and on what charge or charges to bring. ${ }^{136}$

The BIA has also found that the statute supports the choice of DHS instead to place individuals who may be subject to expedited removal in a regular removal proceeding. While one part of the statute states that an officer faced with arriving noncitizens who are inadmissible for reasons of fraud or a lack of proper documentation "shall order the alien removed from the United States without further hearing or review," 137 the statutory language also considers these same individuals for regular removal proceedings. As articulated by the BIA:

$[\mathrm{W}] \mathrm{e}$ find that the statutory scheme itself supports our reading that the DHS has discretion to put aliens in section 240 removal proceedings even though they may also be subject to expedited removal under section 235(b)(1)(A)(i) of the Act. Section 235(b)(2)(A) of the Act provides that "in the case of an alien who is an applicant for admission, if the examining immigration officer determines that an alien seeking admission is not

${ }^{133} I d$. (emphasis added).

134 See INA \238(b)(1), 8 U.S.C \ 1228(b)(1) (2014) (internal citations omitted).

135 Matter of E-R-M- \& L-R-M-, 25 I. \& N. Dec. 520 (BIA 2011). Notably, the Board itself acknowledged that placing individuals in removal proceedings would be preferable. "The respondents are not prejudiced by their placement in section 240 removal proceedings and, in fact, have more rights available to them in proceedings under section 240 than in expedited removal proceedings, where aliens may only raise persecution-related relief." Id.

136 Matter of E-R-M- \& L-R-M-, 25 I. \& N. Dec. 520.

137 See INA 235(b)(1)(A)(i), 8 U.S.C. $\int 1235(b)(1)(A)(i)(2014)$. 
clearly and beyond a doubt entitled to be admitted, the alien shall be detained for a proceeding under section 240.138

Agency guidance documents have also affirmed the role of prosecutorial discretion in immigration law. The act of abstaining from enforcing the immigration law against a person through a favorable exercise of prosecutorial discretion can take place at many different stages of the enforcement process, not just the charging stage. Not only may the immigration agency exercise prosecutorial discretion at different stages of enforcement, but it may also use a variety of different tools to carry out this discretion. There are more than twenty different kinds of prosecutorial discretion in immigration law, including, but not limited to: a decision to cancel a charging document called the Notice to Appear, a decision to release a person from detention even if that person legally qualifies for custody, and a decision to not execute a removal order and instead issue a stay of deportation and supervision order for someone who has already been ordered removed. ${ }^{139}$ The seminal guidance document from ICE on prosecutorial discretion identifies "deciding to issue, reissue, serve, file, or cancel a Notice to Appear (NTA)" as among several forms of prosecutorial discretion. ${ }^{140}$ Importantly, the filing of the NTA is a significant point in the immigration enforcement process as it commences a "removal proceeding" pursuant to $\ 240$ of the Act. ${ }^{141}$ In general, while a decision by DHS to refrain from filing an NTA is often viewed as a favorable exercise of prosecutorial discretion (e.g., in the case of a noncitizen who is ineligible for any relief from removal), the filing of an NTA is a positive act for individuals otherwise subject to administrative, expedited, or reinstatement removal because it provides them with the opportunity to apply for relief in a full and fair hearing before a neutral trier-of-fact. ${ }^{142}$ The agency must consider humanitarian factors and the possibility for other relief when deciding to place a person who legally qualifies for speed deportation in removal proceedings instead. ${ }^{143}$

One policy challenge for advocates seeking to rely on guidance documents to advance prosecutorial discretion in these situations is the fact that the enforcement arm of DHS does not support this policy. Instead, ICE supports a policy that discourages NTA issuance in favor of speed deportation regarding prosecutorial discretion. For example, a 2005 DHS memo instructs "We should attempt to discourage issuance of NTAs where there are other options available, such as administrative removal, crewman removal, expedited removal, or reinstatement."144 Arguably, the desire by DHS to discourage NTAs is economically motivated. This is especially true when the noncitizen lacks family ties, equities, eligibility for immigration relief outside of a removal withholding or CAT exemption, or other

138 Matter of E-R-M- \& L-R-M-, 25 I \& N Dec. 520.

139 See Memorandum from Morton, supra note 14; see also CTR. FOR IMmigrants' Rights, PENN. ST. UNIV.

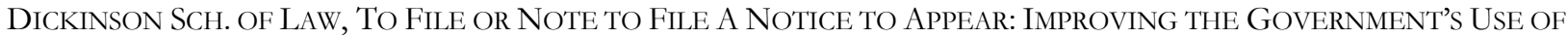
ProseCuTORIAL DisCRETION (2013), available at https://law.psu.edu/sites/default/files/documents/pdfs/NTAReportFinal.pdf.

140 Memorandum from Morton, supra note 14.

1418 C.F.R. $\int 1003.14(a)$.

142 See, e.g., CTR. FOR IMMIGRANTS' RigHTS, supra note 139, at 7 n.9.

143 Memorandum from Morton, supra note 14 ("The following positive factors should prompt particular care and consideration:

- veterans and members of the U.S. armed forces;

- long-time lawful permanent residents;

- minors and elderly individuals;

- $\quad$ individuals present in the United States since childhood;

- $\quad$ pregnant or nursing women;

- $\quad$ victims of domestic violence; trafficking, or other serious crimes;

- individuals who suffer from a serious mental or physical disability; and

- individuals with serious health conditions").

144 Memorandum from Howard, supra note 129. 
humanitarian factors that should be considered. However, it may also be true that without an NTA or removal hearing, the government is unable to identify individuals who might fall into one of these more sympathetic categories. For example, if a person is subject to an administrative removal order because of an alleged aggravated felony conviction, DHS may have no reason to elicit information from the noncitizen about his equities or individual circumstances. ${ }^{145}$ Moreover, even when a person subject to reinstatement or administrative removal expresses a reasonable fear that is eventually documented by an asylum officer, the only forms of relief considered by the immigration judge at a withholding-only hearing are traditional withholding of removal and protections under CAT, neither of which necessitate an exploration into the discretionary factors specific to an individual or potential other relief such as adjustment of status or cancellation of removal.

Each time DHS places a person in administrative, expedited or reinstatement of removal without consideration of (1) specific individual factors like family in the United States or (2) ambiguities surrounding the underlying conduct giving rise to removal and other humanitarian circumstances, DHS is failing to exercise prosecutorial discretion. For example, in regards to Eduardo, DHS could use its discretion under the statute or general principles of prosecutorial discretion to place Eduardo in regular removal proceedings by filing a Notice to Appear in lieu of issuing him an administrative removal order. The benefit for Eduardo is the opportunity to apply for relief from removal such as adjustment of status based on marriage to a United States citizen and a waiver of inadmissibility based on his criminal conviction. Eduardo or his counsel would also have the opportunity to challenge removability before the immigration judge, but DHS placing Eduardo into removal proceedings would not automatically lead to relief for Eduardo. It would provide him with a day in court and the opportunity to seek relief and related waivers from an immigration judge, which are not available to individuals subject to a final administrative removal order.

\section{CONCLUSION}

This Article began with an examination of deportations resulting from the expedited removal, administrative removal, and reinstatement of removal orders and considered whether these programs are good policy following the framework outlined in Mathews $v$. Eldridge. This Article then examined the degree to which the immigration agency has discretion to place individuals subject to a speed removal program into regular removal proceedings.

DHS should provide a fair day in court for those who qualify for relief from removal or whom the administration has determined warrant protection from removal based on individual equities. ${ }^{146}$ DHS could issue a guideline stating that any person facing a legally sufficient charge or determination that he is removable or inadmissible through expedited, administrative, or reinstatement of removal should be automatically screened under the following factors to determine if a regular full court proceeding is appropriate:

145 One scholar argues that "court-observers, advocates, and federal judges frequently note the fervent manner in which some ICE attorneys prosecute removal cases by pursuing inaccurate or inflated grounds for removal, refusing to negotiate, stipulate, or even communicate with noncitizens or their representatives before hearings; failing to turn over evidence bearing on removability; and opposing discretionary relief no matter how clear the merits or how strong the equities." Jason A. Cade, The Challenge of Seeking Justice Done in Removal Proceedings, 89 TUL. L. REV. (forthcoming 2014).

146 Possibly, a full review and modification of immigration prosecutorial discretion would reduce the number of noncitizens who are targeted for enforcement in the first place but a discussion of broader administrative solutions like deferred action are beyond the scope of this Article. 
- $\quad$ eligibility for relief from removal, including, but not limited to, challenges to removability, adjustment of status or viable asylum claims;

- $\quad$ veterans and members of the U.S. armed forces;

- $\quad$ long-time lawful permanent residents;

- $\quad$ minors $^{147}$ and the elderly;

- $\quad$ individuals who have lived in the United States since childhood;

- $\quad$ pregnant or nursing women;

- $\quad$ victims of domestic violence; trafficking, or other serious

crimes;

- parents of children who are US citizens or lawful permanent residents;

- individuals who suffer from a serious mental or physical disability; and

- $\quad$ individuals with serious health conditions. ${ }^{148}$

As part of this new process, DHS could create a screening form for officers to use in conjunction with its decision about whether or not to place a person in a speed deportation. As a legal mater, this screening would not undermine the existing statutory framework for speed deportation. With any proposal, screening individuals may raise costs, but they are necessary to ensure the agency carries out its own policy in a prudent manner. At a minimum, such measures can save the agency costs associated with litigation, damaging news stories, and demands from advocates and attorneys for better solutions.

While the Article supports the authority and use of discretion by DHS to place noncitizens subject to a speed removal into removal proceedings before an immigration judge, it is necessary to also consider the degree to which this position can be reconciled with the policy challenges faced by immigration courts. It is a difficult task to address the tension between this Article's recommendation and the desire to boost the number of cases by employing prosecutorial discretion in favor of NTAs for individuals who might ordinarily qualify for a speed deportation program in the face of an overstretched immigration court system. However, it may very well be worth the expense to protect the noncitizen from removal or at the very least provide her with the dignity and protection of a day in court. Moreover, there are costs associated with the family members and responsibilities a deportee leaves behind, for example, the primary care for a minor child who is a United States citizen or full time employment for a burgeoning American company. ${ }^{149}$

147 This category should include unaccompanied minors based on a plain reading of the term and the recent policy announcements by the Administration to improve safeguards for this population. See, e.g., Press Release, Dep't of Justice Office of Pub. Affairs, Justice Department and CNCS Announces New Partnership to Enhance Immigration Courts and Provide Critical Assistance to Unaccompanied Minors, (June 6, 2014), (available online at

http://www.justice.gov/opa/pr/2014/June/14-ag-609.html).

148 Several of these factors are classified as warranting particular consideration for a favorable act of prosecutorial discretion in Memorandum from Morton, supra note 14.

${ }^{149}$ As synthesized in one article: “The deportations [of parents] have a ripple effect, advocates say. A 2010 Urban Institute study looked at the consequences of parent arrest, detention and deportation on nearly 200 children from 85 families in six locations. Most families lost a working parent, and housing instability and food insecurity were prevalent. About two-thirds of the children experienced changes in their eating and sleeping habits in the months afterward. More than half said they cried a lot and were more fearful. A third showed more anger or aggression." Michael Alison Chandler, Deportations of Parents Can Cast the Lives of U.S.-Citizen Kids into Turmoil, THE WASHINGTON POST (Dec. 29, 2013), http://www.washingtonpost.com/local/education/deportations-of-parents-can-cast-the-lives-of-uscitizen-kids-into-turmoil/2013/12/29/abdf23aa-6b4c-11e3-b405-7e360f7e9fd2_story.html; see also Eli Saslow, A 'Band-Aid' for 800 Children, The WAshington Post (July 5, 2014), http://www.washingtonpost.com/sf/national/2014/07/05/a-band-aid-for-800-children/. 
If speed deportation programs are here to stay, DHS must operate these programs with an understanding of how discretion fits into this process and protect those who are important additions to the United States. 